\title{
Not Ascertained
}

National Cancer Institute

\section{Source}

National Cancer Institute. Not Ascertained. NCI Thesaurus. Code C67119.

Not learned, discovered, or determined with certainty. 